\title{
Susi Ferfoglia
}

Uniwersytet Papieski Jana Pawta II w Krakowie

Międzyuczelniany Instytut Muzyki Kościelnej, Kraków

\section{Guillaume-Gabriel Nivers $\mathrm{i}$ jego chorat}

„Chociaż ozdobniki, frazowanie oraz styl przedklasyczny Niversa są mało znane, a przez to jego utwory pozostają jeszcze w cieniu, należy on do największych kompozytorów francuskich" - pisze Jean Saint-Arroman w przedmowie do Premier Livre d'orgue Guillaume'a-Gabriela Niversa (ok. 1632-1714)ํ.

Nazwisko Niversa kojarzy się przede wszystkim z muzyką organową złotego okresu francuskiego baroku, zwanego także Grand Siècle. Jest to epoka panowania Ludwika XIV, Króla Słońce, naznaczającego swe królestwo swym stylem, czego symbolem stał się pałac w Wersalu. Nivers, który od roku 1678 był również organistą Kaplicy Królewskiej², a po śmierci kompozytora Henri Du Monta (1684) nauczycielem muzyki królowej, był jednym z najważniejszych przedstawicieli tego okresu; w swojej twórczości stał się wyrazicielem „nowego stylu”, który charakteryzował się większą śpiewnością, a w muzyce organowej rozmaitością w doborze registrów organowych ${ }^{3}$. Przez ponad pół wieku Nivers pracował jako organista w jednej z największych i najważniejszych paryskich parafii - Saint-Sulpice, w której dzięki gorliwości tamtejszych duszpasterzy kwitło życie religijne. Szczególnym szacunkiem kompozytor darzył siostry benedyktynki Najświętszego Sakramentu, które mieszkały na rue Cassette,

1 Por. J. Saint-Arroman, Przedmowa [w:] Premier Livre d'orgue de G.-G. Nivers, faksymile, Fuzeau, 1987.

2 W roku 1678 zmarł organista królewski Jacques Chabanceau de la Barre. Z tego powodu ogłoszono konkurs na stanowisko organisty Kaplicy Królewskiej, o które starał się również Nivers. Tygodnik paryski Mercure Galant podaje, że do konkursu zgłosiło się wielu znakomitych organistów francuskich, co spowodowało, że król na miejsce jednego wybrał aż czterech: J. Thomelina, N. Lebègue’a, J. B. Buterne’a, G. G. Niversa. Jako datę objęcia przez nich tego stanowiska Mercure podaje dzień 4 lipca 1678 roku. Por. S. Ferfoglia, Msza „alternatim" we wtoskiej i francuskiej muzyce liturgicznej XVII wieku, Kraków 2011, s. 172.

3 Należy również zaznaczyć, że organy epoki Ludwika XIV były instrumentem nowym, zaopatrzonym w trzy klawiatury oraz nowe registry, które stwarzały nowe możliwości brzmieniowe i techniczne. 
niedaleko Saint-Sulpice i z którymi związał się jako organista i nauczyciel muzyki. Od roku 1686 był również nauczycielem muzyki w słynnej szkole dla zamożnych dziewcząt Saint-Cyr koło Wersalú .

Mało kto natomiast kojarzy nazwisko Niversa z chorałem gregoriańskim. W roku 1683 Nivers opublikował Dissertation sur le chant grégorien (Dysertacja na temat choratu gregoriańskiego), dzieło teoretyczne, w którym w sposób bardzo rzetelny i dokładny podał „właściwe” reguły chorału gregoriańskiego. Jak to się stało, że organista i kompozytor przede wszystkim muzyki organowej stał się gorliwym obrońcą i krzewicielem chorału gregoriańskiego? Co spowodowało, że Nivers wziął na siebie odpowiedzialność, aby ten najstarszy śpiew Kościoła oczyścić ze wszelkich nadużyć i przyczynić się do jego rozpowszechnienia w najczystszej formie? Aby zrozumieć to jego zamiłowanie do chorału, należy przede wszystkim zapoznać się z atmosferą, która panowała w parafii Saint-Sulpice i która niewątpliwie wpłynęła na to, że Nivers stał się przede wszystkim kompozytorem i obrońcą muzyki kościelnej, a w tym zwłaszcza chorału gregoriańskiego.

\section{Zaangażowany parafianin}

Nivers rozpoczął swoją pracę jako organista w parafii Saint-Sulpice, w której panowała szczególna atmosfera. Księża w niej działający dbali o życie duchowe swych parafian. Dzięki ich staraniom i zaangażowaniu parafia ta stała się żywym przykładem, jak można zastosować reformę katolicką po Soborze Trydenckim5.

W celu lepszego zrozumienia wpływu tego środowiska na Niversa spróbujemy pokrótce przedstawić najważniejsze wydarzenia w parafii w okresie, gdy jej proboszczem był ks. Jean-Jacques Olier (1608-1657), który pozostawił w jej życiu najtrwalszy ślad. Zafascynowany modelem życia i duszpasterzowania św. Karola Boromeusza z Mediolanu oraz bliższych mu przykładów ze środowiska

4 Więcej na temat życia i działalności Niversa można znaleźć w S. Ferfoglia, Msza „alternatim”..., dz. cyt., s. 161-166.

5 Należy zwrócić uwagę, że decyzje Soboru Trydenckiego nie były we Francji oficjalnie uznawane, a większość biskupów ociągała się z wprowadzeniem ich w życie. Bardzo ważną rolę we wprowadzeniu reform soborowych we Francji odegrał św. Karol Boromeusz, biskup Mediolanu, który w drugiej połowie XVI wieku był sekretarzem stanu we Francji. W roku 1574 spotkał się nawet z królem Henrykiem III, na którym wywarł ogromne wrażenie. Dzięki temu król mianował na arcybiskupa Aix ucznia św. Karola Boromeusza, Aleksandra Canigiani, który zaczął wprowadzać w życie reformę trydencką. W jego ślady poszło jeszcze kilku biskupów francuskich, którzy m.in. podjęli decyzję o ustanowieniu seminariów. Por. S. Ferfoglia, Msza „alternatim”..., dz. cyt., s. 167. 


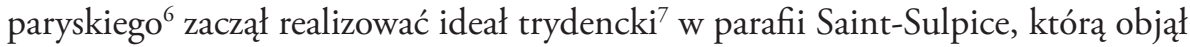
w roku 1642. Parafia Saint-Sulpice była obok parafii Saint-Eustache jedną z największych w Paryżu. Ks. Olier założył w niej wspólnotę księży, którzy mieli na celu służyć wszystkim rejonom tej parafii, aż po te najbardziej oddalone. Na terenie parafii założył seminarium. Od seminarzystów wymagał, aby pomagali księżom we wszystkich obowiązkach: w odprawianiu oficjum, w głoszeniu kazań, w katechizowaniu, w dziełach miłosierdzia. Poprzez założenie seminarium niedaleko uniwersytetu Sorbonne proboszcz z Saint-Sulpice pragnął stworzyć silne środowisko dla studentów teologii, którzy mogliby w nim znaleźć odpowiednią pomoc dla własnego rozwoju i pogłębienia wiary. Dość szybko seminarium to zaczęło się wyróżniać spośród innych, a jego absolwenci otrzymywali ważne funkcje kościelne ${ }^{8}$ Z niego wywodziła się wielka liczba biskupów francuskich, którzy odegrali znaczącą rolę w Kościele francuskim w XVII i XVIII wieku?

Parafia ta wyróżniała się również wielkim nabożeństwem do Najświętszego Sakramentu. Proboszcz Olier w pierwszą niedzielę sierpnia celebrował rokrocznie nabożeństwo wynagradzające za grzechy popełnione przeciwko „Jezusowi Chrystusowi obecnemu w Najświętszym Sakramencie”, a w kościele Saint-Sulpice ustanowił wieczystą adorację. Dbał o to, aby wierni czcili Najświętszy Sakrament poprzez adorację oraz 40-godzinne nabożeństwo. Za przykładem parafii Saint-Sulpice pospieszyły inne parafie paryskie ${ }^{10}$.

Dzięki swojej gorliwej działalności proboszcz Olier zyskał przychylność Rzymu i dworu królewskiego. $Z$ zaangażowaniem wprowadzał w życie zalecenia

6 Są wśród nich Adrien Bourdoise z parafii Saint-Nicolas-du-Chardonnet w Paryżu, św. Wincenty á Paulo oraz Charles de Condren, którzy swoją duchowością i gorliwością zainspirowali proboszcza parafii Saint-Sulpice. Por. C. Davy-Rigaux, Guillaume-Gabriel Nivers. Un art. Du chant grégorien sous le règne de Louis XIV, Paris 2004, s. 13-14.

7 Sobór Trydencki nie był tylko soborem doktrynalnym, ale przede wszystkim soborem dyscyplinarnym i reformatorskim. Wniósł do Kościoła ogólną odnowę życia: odnowę episkopatu, duchowieństwa, instytucji kościelnych oraz kultu Bożego. Odnowa ta obejmowała instytucje, ale była również odnową duchową i moralną, którą Kościół realizował poprzez głoszenie kazań i katechizację społeczeństwa. To wszystko ks. Olier chciał wprowadzić do swojej parafii, uwzględniając warunki Kościoła francuskiego. Por. J.-Y. Hameline, Le plain-chant dans la pratique ecclésiastique aux lendemains du Concile de Trente et des réformes postconciliaires, [w:] Plain chant et liturgie en France au XVIIe siècle, red. J. Duron, Versailles 1997, s. 13.

8 Ludwik XIV w uroczystej deklaracji z 15 grudnia 1698 roku na rzecz rozwoju seminariów podkreślił, że ważną rolę dla rozwoju wiary odgrywają dobrze przygotowani księża, którzy będą mogli dobrze pełnić funkcje im powierzone. Por. C. Davy-Rigaux, Guillaume-Gabriel Nivers..., dz. cyt., s. 17.

9 Por. tamże, s. 14-15.

${ }^{10}$ Por. tamże, s. 15-16. 
Soboru Trydenckiego i uświadamiał księży, aby odpowiedzialnie służyli Kościołowi hierarchicznemu, w którym ważną rolę odgrywają sakramenty i ceremonie ${ }^{11}$.

Wśród księży, którzy również w sposób znaczący przyczynili się do reformy w Saint-Sulpice, był ks. Charles Picoté (1597-1679). Kapłan ten już wcześniej znalazł się u boku ks. Oliera w małej wspólnocie księży, którą ks. Olier założył w Vaugirard (jedna z dzielnic Paryża). Kiedy ks. Olier stał się proboszczem w Saint-Sulpice, ks. Picoté przeniósł się do tej samej parafii. W sposób szczególny przyczynił się do założenia klasztoru ss. benedyktynek Najświętszego Sakramentu, które nieustannie otaczały księży z Saint-Sulpice szczególną modlitwą ${ }^{12}$. Był również w dobrym kontakcie z młodym jeszcze wtedy Niversem, który także miał pewien wpływ na formację sióstr z tego klasztoru, stając się u nich głównym organistą i nauczycielem muzyki.

Kolejny ksiądz, który miał dobry kontakt z Niversem, to Antoine Raguier de Poussé (1617-1680). Został on proboszczem tejże parafii po ks. Bretonvilliers ${ }^{13}$. Ks. de Poussé cieszył się wielkim szacunkiem wśród współczesnych. Jego kontakty z Niversem znajdują odzwierciedlenie w dwóch dokumentach: w umowie małżeńskiej z 21 września 1668 roku, w której został przedstawiony jako doktor Sorbony i proboszcz w Saint-Sulpice, oraz w liście przyjaciół i krewnych przyszłych małżonków ${ }^{14}$.

Nie można więc mieć wątpliwości: młody Nivers był od samego początku naznaczony wyjątkowością tego miejsca, które tętniło życiem wiary i pięknem liturgii. Sposób, w jaki komponował i grał na organach, wiązał się więc z sytuacją panującą w Saint-Sulpice. Jak już wspomniano, księża z tej parafii podobnie jak ich wielki poprzednik w Mediolanie św. Karol Boromeusz, chcieli swoją postawą i działalnością urzeczywistnić zalecenia reformy trydenckiej w czasie, gdy Kościół katolicki czuł się zagrożony przez protestantyzm. Ich troska o piękno ceremonii, które były dopracowane w najdrobniejszych szczegółach, kształtowała również osobowość muzyczną młodego jeszcze wówczas Niversa.

${ }^{11}$ Parafia Saint-Sulpice podlegała bezpośrednio pod jurysdykcję papieża poprzez opata z sąsiedniego Saint-Germain-des-Prés; pod jurysdykcję arcybiskupa Paryża przeszła dopiero w roku 1669.

${ }^{12}$ Pełna nazwa brzmi: Mniszki Benedyktynki od Nieustającej Adoracji Najświętszego Sakramentu. Nazwa łacińska: Moniales Ordinis S. Benedicti Adorationis Perpetuae Sanctissimi Sacramenti (OSB ap). Zgromadzenie powstało we Francji w XVII wieku w łonie rodziny monastycznej św. Benedykta jako gałą́ kontemplacyjna, klauzurowa, o charakterze wynagradzającym. http://www.benedyktyni.pl/benedyktynki/sakramentki.

${ }^{13}$ Ks. Bretonvilliers przejął prowadzenie seminarium po śmierci ks. Oliera. Por. C. Davy-Rigaux, Guillaume-Gabriel Nivers..., dz. cyt., s. 22.

${ }_{14}$ Por. tamże, s. 22-23. 
Nivers był bardzo pobożny. Traktował swoją pracę jako powołanie. Może dlatego w starych biografiach figuruje często jako ksiądz ${ }^{15}$. Taką pobożność prawdopodobnie wpoiła mu jego matka Geneviève Guignard, u boku której żył do chwili jej śmierci. W swojej Dysertacji na temat chorału gregoriańskiego napisał, że całe swoje życie pragnie poświęcić twórczości typowo kościelnej. Według niego muzyk kościelny powinien żyć liturgią. Poprzez wyrażenie musique purement ecclésiastique oddawał muzykę, która była przeznaczona do liturgii, a zaliczał do niej przede wszystkim chorał gregoriański oraz jego "pochodne” jak plan-chant musical i utwory wokalne, które były wykonywane na przemian $\mathrm{z}$ organami ${ }^{16}$.

Cel, jaki postawił sobie Nivers, doskonale korespondował z wizją księdza Oliera, który chcąc wzbudzić u swoich parafian poczucie majestatu Bożego, starał się, aby liturgia w kościele Saint-Sulpice była na najwyższym poziomie, bogata śpiewem, psalmami i procesjami, przyozdobiona pięknymi paramentami liturgicznymi.

Nivers w swojej Dissertation sur le chant grégorien podkreślał, że chorał gregoriański ma pierwsze miejsce w muzyce kościelnej. Inspirowany przez reformę Trydentu, którą chciał w pełni realizować, poświęcił swój talent muzyka - organisty i kompozytora - wspólnej sprawie, jaką było piękno liturgii, i w ten sposób przyczynił się do ogólnego rozwoju muzycznego w Kościele ${ }^{17}$. Z niektórych fragmentów omawianej Dysertacji można się dowiedzieć, jaka jest według Niversa rola organisty w kościele. Zważając na to, że w Kościele popełniano wówczas również wiele nadużyć i błędów, podkreślał, że organista powinien przede wszystkim grać w sposób tak pokorny i pobożny, aby swoimi przyjemnymi dźwiękami dotykał serc ludzi. Muzyka powinna pobudzać ku większej pobożności i służyć większej chwale Bożej ${ }^{18}$.

W roku 1681 miało miejsce szczególne wydarzenie, które pozwoli nam lepiej zrozumieć osobowość Niversa i jego przywiązanie do parafii Saint-Sulpice. Jest ono udokumentowane w rejestrach obrad administratorów parafii Saint-Sulpice. Pierwszy administrator parafii Saint-Eustache w Paryżu zaproponował Niversowi

\footnotetext{
${ }^{15}$ Niewykluczone, że Nivers myślał o kapłaństwie, skoro ożenił się dopiero w wieku 36 lat.

${ }^{16}$ Por. C. Davy-Rigaux, Guillaume-Gabriel Nivers..., dz. cyt., s. 23.

${ }_{17}$ Por. tamże, s. 24.

18 «Mais on n'a pas lieu présentement de se plain de ces sortes d'abus, puisque les organistes de cotemps, au moins la plupart qui sont connus, touchent l'orgue d'une manière si modeste et si dévote qu'ils touchent autant le coeur par leurs modulations agréables qu'ils flattent l'oreille par la douceur de leurs accords. Et pourvu que tout cela se fasse dans le dessein de louer Dieu, tant de la part des organistes que des auditeurs cela suffit pour exciter la devotion». G. G. Nivers, Dissertation sur le chant grégorien, s.18. Tłumaczenia z języka francuskiego w artykule pochodzą od autorki.
} 
pracę na stanowisku organisty, proponując wysokie wynagrodzenie. Kompozytor jednak odmówił, odpowiadając, że w parafii Saint-Sulpice pracuje ponad 27 lat i że żywi do niej wielki szacunek, dlatego nie chce jej zostawić i woli zarabiać 500 liwrów na rok, jak do tej pory, niż w Saint-Eustache 800 liwrów $^{19}$.

Nivers pracował w Saint-Sulpice do swej śmierci, czyli w sumie około 62 lata i, jak tego dowodzi odnotowane wydarzenie, był z tą parafią bardzo związany.

\section{Dissertation sur le chant grégorien (1683)}

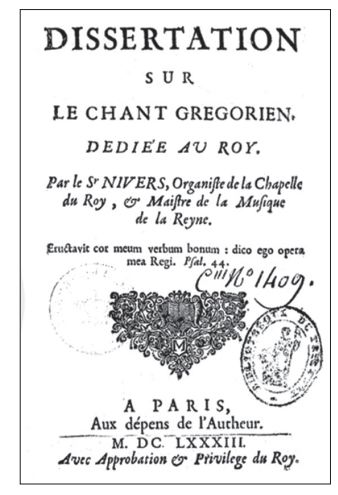

W przedmowie do Dysertacji na temat śpiewu gregoriańskiego Nivers wyjaśnia, czemu ma ona posłużyć:

„Oto cel tego dzieła,

1. pokazać doskonałość śpiewu gregoriańskiego;

2. przedstawić nadużycia, które weszły do niego;

3. sformułować reguły i główne powody korekt, które zostały naniesione w kilku miejscach przy odwołaniu się do niezbędnych autorytetów:

żeby w końcu dojść do wniosku, że chorał gregoriański (oczyszczony z swoich błędów) jest najbardziej autentycznym i najbardziej znaczącym ze śpiewów kościelnych" ${ }^{20}$.

${ }_{19}$ Por. tamże.

20 «Voicy donc la fin de cet ouvrage, 1 . De monstrer l'excellence du chant gregorien; 2. d'exposer les abus qui s'y sont glissez; 3. De produire les regles et les raisons principals des corrections qui s'y sont faites en plusieurs lieux avec les authoritez necessaires: pour enfin conclure que le chant gregorien (purge de ces erreurs) est le plus authentique et le plus considerable 
W roku 1683, gdy Dissertation sur le chant grégorien ujrzała światło dzienne, Nivers miał około 51 lat i od ponad trzydziestu lat piastował już stanowisko organisty w kościele Saint-Sulpice w centrum Paryża, od pięciu lat był organistą Kaplicy Królewskiej oraz od dwóch lat nauczycielem muzyki królowej. Do tego czasu kompozytor miał już na swoim koncie liczne publikacje, wśród nich trzy Livres d'orgue (Ksiegi organowe, 1665, 1667, 1675), Graduel (Graduat) i Antiphonaire à l'usage des religieuses (Antyfonarz do użytku zakonów, 1658, 1671) oraz Antiphonaire des prémontrés (Antyfonarz do użytku premonstratów $\left.{ }^{21}, 1680\right)^{22}$.

Dysertacje na temat choratu gregoriańskiego za życia Niversa bardzo podziwiano, po jego śmierci zaś bardzo krytykowano. W roku 1668 kompozytor opublikował Graduel i Antiphonaire, które również zostały ostro skrytykowane. Pod koniec XIX wieku doszło bowiem do pewnej polemiki w sprawie chorału Niversa pomiędzy Nisardem i członkami Komisji ds. muzyki kościelnej z Reims i Cambrai. Nisard uważał, że Nivers nie podszedł do odnowy chorału w sposób archeologiczny, lecz chciał (do czego zresztą król go zobowiązał) doprowadzić do jednolitości śpiewu religijnego we Francji. Czytając natomiast Dysertację, nie można mieć wątpliwości, że Nivers darzył wielkim szacunkiem chorał gregoriański jako najbardziej znaczący śpiew Kościoła, co nie było tak powszechne w jego czasach ${ }^{23}$.

W roku publikacji Dysertacji Nivers wziął udział w konkursie o stanowisko organisty Kaplicy Królewskiej. Pozwala to zrozumieć, dlaczego pierwsze jej strony zawierają pochwałę króla, który dbał o kult Boży.

Dysertacja Niversa nie jest ani pierwszym, ani ostatnim jego dziełem teoretycznym. Już w roku 1667 opublikował on Traité de la composition de musique $e^{24}$, a w roku 1683 l'Art d'accompagner sur la basse continue pour l'orgue et le clavecinn ${ }^{25}$ oraz Méthode certaine pour apprendre le plein-chant de l'Eglise $e^{26}$. Wymienione dzieła mają charakter bardziej pedagogiczny, którego Dysertacja jest pozbawiona. Nivers wykorzystuje w niej elementy sztuki retorycznej połączonej z rozumowaniem

de tous les chants ecclésiastiques». G. G. Nivers, Préface [en:] Dissertation sur le chant grégorien, dz. cyt.

${ }^{21}$ Premonstranci (Premonstratensi) - norbertanie, zakon założony w roku 1120 przez św. Norberta z Xanten w miejscowości Prémontré koło Laon w Francji.

${ }^{22}$ Szczegółowy wykaz publikacji Niversa dotyczących chorału gregoriańskiego znajduje się w C. Davy-Rigaux, Guillaume-Gabriel Nivers..., dz. cyt., s. 413 nn. Ogólny wykaz dzieł Niversa znajduje się również w S. Ferfoglia, Msza „alternatim”..., dz. cyt., Kraków 2011, s. 229-232.

${ }^{23}$ Por. S. Ferfoglia, Msza „alternatim”..., dz. cyt., Kraków 2011, s. 173.

${ }^{24}$ Paris, u Autora, R. Ballard, 1667.

${ }_{25} \mathrm{~W}$ Motets à voix seule, accompagnée de la Basse continue, Paris, u Autora, 1689.

${ }^{26}$ Paris, Ch. Ballard, 1698. 
autonomicznym i racjonalnym, które są typowe dla takiego rodzaju dysertacji XVII-wiecznej. W niej odzwierciedla się również klasyczna formacja, którą Nivers otrzymał na Sorbonie ${ }^{27}$.

Dysertacja zawiera osiemnaście rozdziałów, które można podzielić na trzy części:

- rozdziały I-III: ukazanie wspaniałości chorału gregoriańskiego;

- rozdziały IV-VIII: nadużycia, które można spotkać w publikacjach i rękopisach chorałowych w ciągu wieków;

- rozdziały IX-XVII: wykaz reguł, dzięki którym według Niversa można poprawić nadużycia chorału gregoriańskiego;

- rozdział XVIII: ostatni, zamykający.
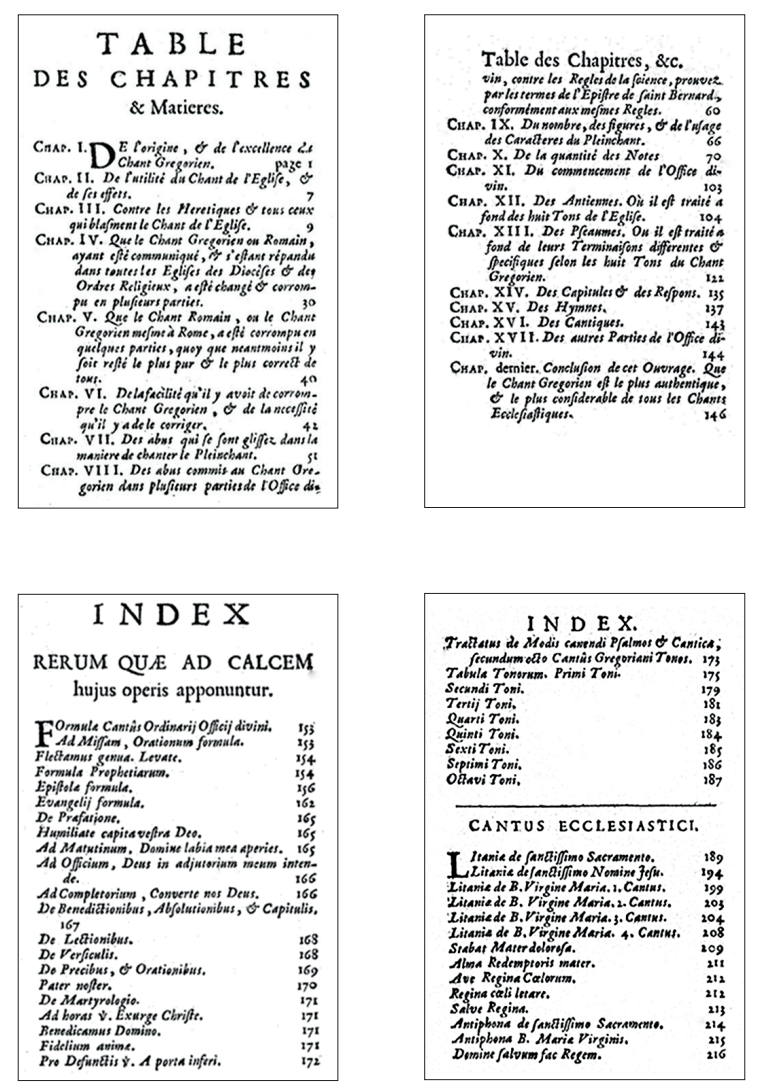

${ }^{27}$ Przypominamy, że w roku 1661 Nivers otrzymał na uniwersytecie paryskim stopień naukowy Maître ès Arts, który można było uzyskać na zakończenie studiów Faculté des Arts (czyli kierunku humanistycznego). Por. S. Ferfoglia, Msza „alternatim”..., dz. cyt., s. 162. 
W Dysertacji znajdziemy również aneks muzyczny, który zawiera formuły modlitw, błogosławieństwa, epistoły, ewangelie zebrane pod tytułem Formulae Cantus ordinarii Officii Divini. Do tego dołączone są również tony psalmowe i kantyki oraz śpiewy chorałowe, prawdopodobnie napisane przez Niversa. Dysertacja odzwierciedla charakterystyczny rys Niversa i jego zaangażowanie jako kompozytora „muzyki wyłącznie kościelnej”28.

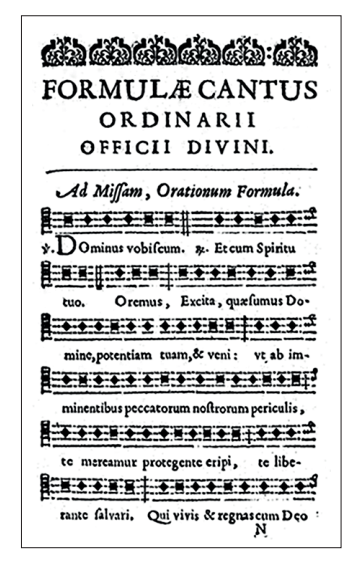

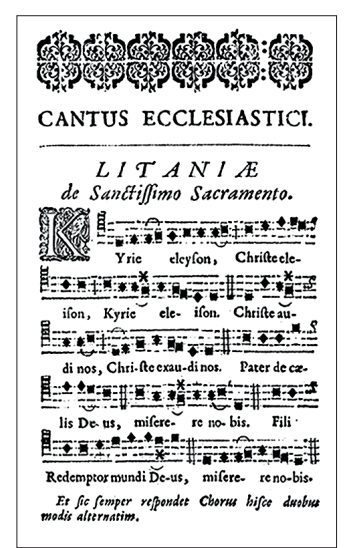

\section{Bienséance ecclésiastique, czyli „poprawność kościelna”}

Chcąc przywrócić do chorału gregoriańskiego pewien porządek, Nivers wyjaśniał, że należy najpierw poprawić błędy, które się do niego wkradły. Zwrócił uwagę na „poprawność” ${ }^{29}$, którą trzeba uwzględnić w śpiewie kościelnym. Co Nivers rozumiał poprzez „poprawność kościelną”?

W pierwszym rzędzie kompozytor potępiał tych wszystkich, którzy komponując śpiewy kościelne, wzorowali się na śpiewie świeckim. W takich śpiewach bowiem nie ma nic z ducha Kościoła. Nie potępiał jednak stwarzania nowych śpiewów ani ich ozdabiania, gdyż na wzór kaznodziejów, którzy „ozdabiają” swoje kazania, można również ozdobić śpiew kościelny.

28 "de musique purement ecclésiastique», por. C. Davy-Rigaux, Guillaume-Gabriel Nivers..., dz. cyt., s. 34 .

${ }^{29}$ "Le changement du chant corrompu, et le retranchement de ses erreurs, ne peuvent qu'apporter l'order et la décence ecclésiastique». G. G. Nivers, Dissertation..., dz. cyt., rozdz. VI, s. 48. 
[...] jeśli kaznodzieje wzmacniają [Pismo Święte] i wyjaśniają niektórymi ozdobnikami retorycznymi, jest to na chwałę Bożą i na zbudowanie i nawrócenie słuchaczy: $\mathrm{w}$ ten sam sposób można ozdobić śpiew niektórymi modulacjami regularnymi, byle by były zgodne z ideą gregoriańską i poprawnością kościelną dla pociechy wiernych ${ }^{30}$.

Według Niversa nie wystarczy jedynie wykluczyć z liturgii wszelkich wpływów muzyki świeckiej. Śpiewy kościelne powinny przede wszystkim uwzględnić „poprawność kościelną” i powinny być podporządkowane określonym regułom. Uwzględniać „poprawność kościelną” oznacza śpiewać w sposób prawidłowy ${ }^{31}$. Śpiewać prawidłowo to w pierwszym rzędzie zwrócić uwagę na wewnętrzny sens tekstu ${ }^{32}$. Z tego wynika, że należy zadbać o to, by słowa zostały przekazane w poszanowaniu ich prozodii i gramatyki. Dlatego autor stawia pytanie:

Jeśli jest jakaś sylaba długa, dlaczego dać jej krótką nutę? Jeśli sylaba jest krótka, dlaczego jej dać jedną albo więcej długich nut? Dlaczego trzeba powywracać wszystkie te reguły, wbrew samemu znaczeniu słów, źle stawiając przecinki, a kadencje i zakończenia bez respektowania sensu? ${ }^{33}$

Owa „poprawność kościelna” oznacza również to, że poprzez śpiew należałoby podkreślić stopień danego święta ${ }^{34}$.

30 «[... si les predicateurs l'amplifient [l'Écriture Sainte] et l'expliquent avec quelques ornements de rhetorique, ce n'est qu'à la gloire de Dieu, à l'edification et conversion des auditeurs: ainsi l'on peut orner le chant de quelques modulations regulieres, pourveu que ce soit conformément à l'idée gregorienne, et à la bienséance ecclesiastique, pour la consolation de fideles». Tamże, s. 50.

31 «Et si l'on parle de Dieu correctement, pourquoy ne chantera-t'on pas ses loüanges aus correctement?» Tamże, s. 50.

32 «Si donc le sujet demande de la joye intérieure, pourquoy temoignerons-nous de tristesse par nos chant lugubres, et au contraire?» Tamże.

33 "S'il y a une syllabe longue, pourquoy luy Donner une note breve? S'il y a une syllabe breve, pourquoy lui donner une ou plusieurs notes longues? Pourquoy renverser tout ses regles, contre le sens mesme des paroles, avec des virgules de chant mal à propos, des cadences ou conclusions à contre sens?» Tamże.

34 «[...] il y a certaines antiennes, et des plus grandes festes de l'année don't le chant est si simple et ferial, qu'elles ressemblent plustost à des oraisons que l'on recite tout droit, qu'à des antiennes don't le chant doit estre varié. [...] Ces chants veritablement pour des antiennes solennelles n'ont pas la gravité et la bienséance ecclesiastique, qui consiste à varier et composer un nombre raisonnable de notes sur certaines syllables que la prudence du compositeur y sçait imposer». Tamże, rozdz. X, s. 86-87. 
Nivers starał się, aby chorałowi gregoriańskiemu przywrócono należyte miejsce w Kościele. Wśród niemałego zamieszania, tak z punktu widzenia muzycznego, jak i wydawniczego, Nivers chciał przede wszystkim sprecyzować właściwą formę chorału gregoriańskiego, dać mu właściwe miejsce, ale również chciał otoczyć śpiew kościelny staranną troską, ponieważ uważał, że jest on jednym z podstawowych elementów liturgii i dlatego powinien podlegać tym samym regułom co tekst liturgiczny, z którym tworzy jedność. Kompozytor uważał, że śpiew służy Pismu Świętemu i świętym słowom, które Kościół daje nam do ust, żeby wychwalać Pana ${ }^{35}$.

W Dysertacji Nivers kładzie nacisk na trzy elementy, które są ważne w relacji pomiędzy słowem a śpiewem:

- ogólny sens tekstu,

- sens frazy,

- wymowę.

\section{Ogólny sens tekstu}

Według Niversa na pierwszym miejscu kompozytorzy powinni zdobyć wiedzę humanistyczną i dzięki temu odpowiednio wyrażać sens Pisma ${ }^{36}$. Sens ten można oddać dzięki odpowiednim modusom (tonom kościelnym), które wyrażają różne „afekty” zawarte w słowach. Prawdopodobnie Nivers nawiązuje w tym miejscu do Jumilhaca, który mówił o różnych „afektach” zawartych w modusach i ich wpływie na człowieka. Nivers w swojej pracy nie zamieścił wykazu cech charakterystycznych każdego z modusów ${ }^{37}$, ograniczył się do najogólniejszych cech, występujących w modusach, używając następujących określeń: „szlachetny”, „wesoły”, „poważny” albo „smutny”.

35 «[...] l'Ecriture sainte n'est pas faite pour le chant ou après le chant, mais le chant est fait après et pour l'Ecriture sainte, et pour les paroles que l'Eglise nous met en la bouche pour chanter les louanges de Dieu». Tamże, s. 93.

36 «[... est absolument necessaire aux compositeurs d'avoir la science des lettres [...] afin d'exprimer, par les modes specifiques et par les modulations propres, essentielles, et convenables aux sujets differens des matieres, le sens des Escritures». Tamże, rozdz. VII, s. 55.

${ }^{37}$ Gregorianiści epoki Grand Siècle zwracali wielką uwagę na to pojęcie. Jumilhac podkreśla, że pojęcie to było znane już u starożytnych, poczynając od Ptolomeusza aż do Gwidona z Arezzo. O „afektywności” modusów piszą również tacy teoretycy, jak Franchin, Glarean, Kircher i kardynał Bona, Paschal, Millet oraz Saché. Wśród muzyków o „energii” modusów mówi Charpentier. Por. C. Davy-Rigaux, Guillaume-Gabriel Nivers..., dz. cyt., s. 64. 


\section{Sens frazy}

Związek pomiędzy muzyką a tekstem powinien być uwidoczniony również na poziomie frazy. Nivers zauważył, że często interpunkcja w psalmach nie jest dokładna; kropki, przecinki, kadencje śpiewu znajdują się niekiedy w miejscach niezgodnych z sensem słów, dlatego wymagają poprawek. Nie powinno się oddzielać słów, które współtworzą pewien sens, i trzeba zwrócić uwagę na to, żeby interpunkcja w śpiewie była zgodna z interpunkcją frazy. Swoje stwierdzenia Nivers ilustruje wieloma przykładami, w których ukazany zostaje omawiany błąd ${ }^{38}$.

Poniższy przykład z Dysertacji pokazuje bardzo wyraźnie, o jakie błędy Niversowi chodziło.

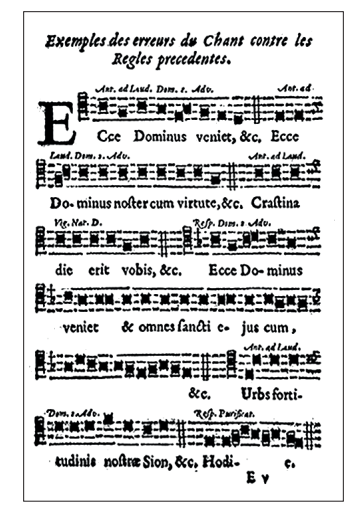

\section{Wymowa}

Dopasowanie śpiewu do tekstu powinno się dokonywać również na poziomie wymowy słów. Żeby osiągnąc dobrą wymowę w śpiewie, melodia powinna uwzględniać reguły gramatyki ${ }^{39}$. Podporządkowanie tekstowi jest szczególnie ważne w śpiewie liturgicznym. Nivers mówi nawet, że dzięki wyśpiewaniu słów w godny sposób dusza zostaje namaszczona przez Ducha Świętego.

${ }^{38}$ Pod tym względem Dysertacja jest dziełem wyjątkowym i bardzo precyzyjnym, gdyż podaje mnóstwo konkretnych przykładów.

39 «Si ces paroles [de l'Église] estant prononcées observant les regles de la grammaire, pourquoy le chant en sera-il exempt? Ou plutost, pourquoy le chant n'aura-t'il pas aussi cet avantage, veu que le chant est une expression plus authentique de la pronunciation des paroles? Si nous parlons de Dieu avec la grace des accens de la quantité, pourquoy n'employerons-nous pas cette mesme grace pour chanter ses loüanges». G. G. Nivers, Dissertation..., dz. cyt., rozdz. X, s. 93. 


\section{Inégalité (nierówność) w chorale gregoriańskim}

Jedną z najbardziej dyskutowanych kwestii w śpiewie są wartości nut. W okresie nas interesującym trwała jedna z najbardziej zagorzałych debat na ten temat. Nivers również włączył się w tę dyskusję. Istotą tej debaty był stosunek śpiewu do tekstu liturgicznego, jego funkcja i rola w świętym oficjum. Podstawowym pytaniem gregorianistów epoki Grand Siècle było: czy w chorale gregoriańskim długość nut zależy od gramatyki i od wymowy słów? Nivers odpowiada twierdząco, dwóch benedyktynów natomiast, Le Clerc i Jumilhac, odpowiada przecząco.

Według Niversa w chorale gregoriańskim należy bronić inégalité (nierówności) w długości nut, ponieważ tylko niewiedza i przypadek doprowadziły do tego, że w chorale wszystkie nuty są równe ${ }^{40}$. Istotą chorału gregoriańskiego nie jest to, że wszystkie nuty są równe, lecz że długie nuty są równe długim, krótkie równe krótkim; z tego wynika, że dwie krótkie to jedna długa ${ }^{41}$. Dla kompozytora chorał powinien być podporządkowany wymowie, ponieważ śpiew jest najbardziej autentyczną ekspresją słów ${ }^{42}$.

Nivers mówi o wartościach égale (równych), które są przeplatane z inégal (nierównymi). Według niego śpiew bez zmian $\mathrm{w}$ długości nut nie jest właściwym śpiewem. Przekonuje nas o tym „dobry gust” (bon gồt), dzięki któremu nie tylko kompozytorzy, ale i inni ludzie odczuwają, że w śpiewie powinien się pojawiać także element inégalité (czyli musi być trochę nierówny) ${ }^{43}$. Gwarantami dobrego gustu w sprawach dotyczących muzyki są kompozytorzy. Niemożliwe jest

40 "[Nous allons] montrer d'une manière concaincante que ce n'est pas la raison d'égalité, (car voilà le seul argument qu'on fait et qui va ester encore renversé) mais l'ignorance, ou le hazard, qui a introduit dans le plainchant de faire longues mesme les syllables breves». Tamże, s. 94.

41 «Trois qualités sont l'essence du plainchant; Planus, c'est àre plain, égal dans toutes ses notes longues; et à proportion, plain, égal dans toutes ses notes brèves. L'essence du plainchant ne consiste pas en ce qu'il doit avoir toutes ses notes égales entièrement, omnes omnio, mais seulement les longues égales aux longues, les brèves égales aux brèves; en sorte que deux brèves ne valent qu'une longue; voilà la priemiere qualité qui constituë l'essence du plainchant, et le fait differer de la musique, laquelle est fondée sur la raison d'inégalité indefinite, parce qu'elle a autant de mesures qu'il y a de parties en la quantité». Tamże, s. 91-92.

42 "[...] que le chant est une expression plus authentique de la pronunciation des paroles». Tamże, s. 93.

43 «[... non seulement tous les compositeurs, mais mesme toutes les personnes de bon goust, ayment mieux (sans mesme faire aucune reflection à la quantité des syllabes) cette mesure égale entremeslée un peu d'inégalité, que cette mesure totalement égale». Tamże, s. 92. 
zatem, żeby chorał gregoriański był pozbawiony jednego z zasadniczych parametrów sztuki muzycznej. Taki chorał byłby, według Niversa, okaleczony. Przeciwnicy inégalité bazowali, według Niversa, na koncepcjach zbyt teoretycznych, które nie liczą się z zasadami sztuki muzycznej.

Nivers zadaje sobie pytanie, czy inégalité jest zgodna z pewną „poprawnością” kościelną, o której była mowa wyżej. Jak się o tym przekonać? I odpowiada na to pytanie z perspektywy dobrego gustu: égalité (równość) nut jest bardziej w stanie zdenerwować słuchacza, niż się mu podobać ${ }^{44}$. Ta racja jest jedną z najważniejszych dla kompozytora.

Istnieje jeszcze jeden aspekt omawianej sprawy. Nivers rozpatruje ją w kontekście religijnej tradycji interpretacji symbolicznej. Inégalité symbolizuje część ziemską i ludzką śpiewu, tzn. jest odbiciem ludzkiej ułomności, świata niedoskonałego; égalité natomiast symbolizuje aspekt doskonały, jest odbiciem Bożej wieczności. Chorał według Niversa jest śpiewem ludzkim, który chciałby osiągnąć trochę doskonałości z drugiego, doskonałego świata, ale nie jest w stanie. Dlatego także $\mathrm{w}$ chorale jest miejsce dla inégalité. Śpiew w pełni égal nie może być nigdy śpiewem ludzkim; jest on zbyt doskonały ${ }^{45}$.

\section{Zakończenie}

Dissertation sur le chant grégorien pozwala nam poznać Niversa jako specjalistę od chorału gregoriańskiego, oddanego jego rozpowszechnianiu. Organista z Saint-Sulpice uważał chorał za nieodzowny element tradycji liturgicznej Kościoła, jakkolwiek nie wolny od deformacji spowodowanych niszczącym działaniem czasu. Wnikliwe podejście Niversa, dość rzadkie w jego epoce, doprowadziło go do poznania wewnętrznej słabości chorału zmienionego w przeciągu stuleci. Nivers chciał z jednej strony zwrócić uwagę na konieczność

44 [...] égalité totale et absoluë des notes est plus capable d'ennuyer que de plaire. Tamże, s. 98.

45 «Enfin, si cette inégalité des notes interrompt quelquefois l'égalité de la mesure, si ces notes brèves qui viennent de temps à la traverse choquent la nature; cela marque et figure merveilleusement les traverses de ce monde, et ses consolations meslées d'amertumes: c'est le partage de l'Eglise militante; cette égalité parfait et perpétuelle represente l'Eglise triomphante, où les Anges et les Bien-heureux ne cessent jamais de chanter, Sanctus, Sanctus, Sanctus. Nous autres qui avons l'honneur de faire icy dans le temps ce que les saints font dans l'Eternité, tantos nous participions à leur joye par la douceur et l'égalité des notes que nous chantons à leur imitation [...], tantos nous éprouvons les contradictions de la nature corrompuë par l'inégalité des notes dans les loüanges que nous rendons à Dieu, lesquelles nous ne pouvons pas chanter en cette vie que tres-imparfaitement». Tamże, s. 99. 
poprawienia błędów i nadużyć w chorale, żeby mu przywrócić właściwą godność, z drugiej zaś strony chciał uwrażliwić władze kościelne, żeby czuwały nad nowymi nadużyciami, które się wkradają do śpiewu. Kwestia ta jest ściśle związana z debatą na temat roli śpiewu w liturgii. W tej dziedzinie Nivers poszedł dalej niż większość jemu współczesnych: zwrócił uwagę na śpiew jako na uprzywilejowany wyraz pobożności. Uznawał śpiew za najbardziej autentyczny wyraz słów, angażujący serce.

Podobnie jak jego koledzy gregorianiści także Nivers odczuwał potrzebę, żeby przestrzegać reguły „poprawności” kościelnej w duchu Soboru Trydenckiego, który chciał promować śpiewanie: reverenter, distincte, devote („z uszanowaniem”, „wyraźnie”, „pobożnie”). Specyfika Niversa polega na tym, że z owej zasady „poprawności” uczynił jedną z podstawowych reguł poprawiania i komponowania chorału. Inna zasada polega na poszanowaniu reguł pewnych, oczywistych i nieomylnych. Nivers uważał, że chorał, tak jak wszystkie śpiewy, czerpie ze sztuki muzycznej i opiera się na ars canora (juxta normas artis canora). Proponował, żeby w tym względzie opierać się na doświadczeniu i praktyce „rzemieślników” śpiewu, którymi są sławni kompozytorzy znający dobrze sztukę muzyczną. W ten sposób sprzeciwił się tym gregorianistom (wśród nich byli Jumilhac i Le Clerc), którzy chcieli poprawiać chorał na bazie reguł naukowych i teoretycznych. Chodziło tu o dwa przeciwstawne stanowiska: według pierwszego rehabilitacja chorału powinna opierać się na teorii. Drugie stanowisko, reprezentowane przez Niversa, opierało się na poszanowaniu reguł sztuki śpiewu i na zasadach „poprawności” kościelnej.

\section{Guillaume-Grabriel Nivers and his chorale}

Guillaume-Gabriel Nivers (ca. 1632-1714), a composer and organist of the Parisian parish of Saint-Sulpice, regarded as one of the keenest advocators of the Gregorian chant in the $17^{\text {th }} \mathrm{c}$. when heated debates on its subject were carried out by the Church. The Gregorianists of Grand Siècle carefully analysed the proper approaches towards this way of singing, how to interpret it, what is the correlation between words and chants, what should be the proper rhythm. Amongst various opinions (e.g. by Jumilhac and Le Clerc) representing purely theoretical approach, Nivers' main idea was to make a choral regain its place as most appropriate during liturgy. For that reason his theoretical work 
Dysertacja na temat choratu gregoriańskiego (Treatise on Gregorian Chant) was wholly written in order to present "proper" rules of the chant, cleansing it of all misinterpretations and misuses to have crept into it over the centuries. In his work GuillaumeGabriel Nivers used his high abilities and paid due respect to tradition when relying on the authorities of the Church, e.g. St. Augustine, St. Gregory or St. Justin. In his approach towards the Gregorian chant he emphasised the principle of Church "correctness" which consisted in:

- excluding from singing all connections with secular music;

- focusing on internal sense of lyrics through „affects” included in particular modes, proper punctuation in texts, and making melodies apply to grammar rules;

- respecting inégalité (inequality) in singing, as resulted from „good taste” and rules of diction. 